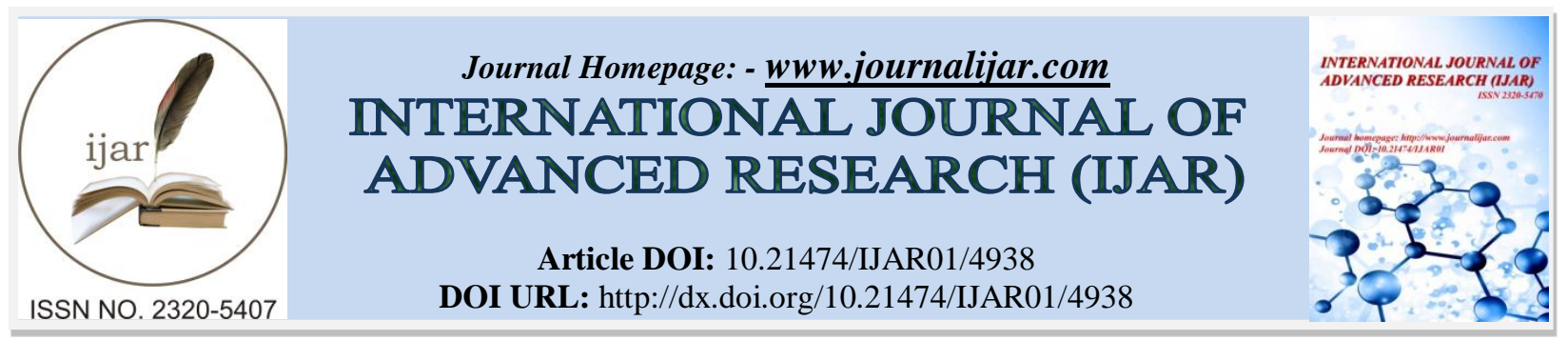

RESEARCH ARTICLE

\title{
OPPRESSION, ALIENATION AND RISE OF PROTESTS: INSIGHTS OF STONE PELTING FROM KASHMIR.
}

Mohmmad Rafi Bhat, Kounser Iqbal and Shugufta Akhtar.

Ph D scholars, Department of Sociology, University of Kashmir.

\section{Manuscript Info}

Manuscript History

Received: 24 May 2017

Final Accepted: 26 June 2017

Published: July 2017

Key words:-

Kashmir conflict, stone pelting,

alienation, protests

\section{Abstract}

When normal outlets of human expression remain choked, catharsis finds its likely way - either through slogans or rocks or violent other means. There are reasons why despite the establishment of a 'democratic' political order in Jammu \& Kashmir, the anger on its streets remains. The fundamental reason is political. There is a feeling of political and economic disempowerment. Kashmiri youth, faced with a strong state and its security apparatus, also nurse feelings of helplessness and powerlessness. Dissent, peaceful or otherwise, has almost always meant persecution. The cumulative result is accumulated anger. The fourth generation of Kashmiris is today doing what the first generation did some 60-70 years ago; they are venting their anger and frustration with the political system through street resistance. Having no platform for expressing their political opinion, they resort to hurling stones. The paper is based on field study in Srinagar. where stone pelting is frequent.

Copy Right, IJAR, 2017,. All rights reserved.

\section{Introduction:-}

It has been around eight decades since the youth of Kashmir first expressed their anger on the streets of Srinagar in 1931. Then the expression of their anger was seen as a sign of political catharsis. Long years of foreign rule and subjugation had brewed up a fury which was looking for a vent. The expression of anger on the streets also sought to re-assert the quest for Kashmiri identity and political emancipation. Today, some eight decades down the line, the expression and the quantum of that youth anger can still be seen in identical forms on Kashmir's streets.

A protest expresses a strong reaction of events or situations. The term protest usually now implies a reaction against something, while previously it could also mean a reaction for something. Protesters may organize a protest as a way of publicly and forcefully making their opinions heard in an attempt to influence public opinion or government policy, or may undertake direct action in an attempt to directly enact desired changes themselves.

Political protests are ubiquitous phenomena. Until the 1970s, the study of social movements was firmly within a diverse sociological tradition that explored the relationship between social structure and political behavior, and was preoccupied with explaining variation in the political orientation of movements: their ideologies, aims, motivations, or propensities for violence. Subsequently, a breakaway tradition redefined the central problem, radically narrowing the scope of interest to the process of mobilization-how social groups, whoever they are and whatever their aims, marshal resources, recruit adherents, and navigate political environments in order to grow and succeed. 
The study of social movements is among one of the largest and most broadly conceived of all the many sub-fields within the discipline of sociology. While some researchers study the rise of specific social movement organizations at particular points in history, other researchers look at macro-level trends and events in an attempt to link various large scale demographic, economic and political transformations to the emergence of regional, national, and even global social movements (Goldstone 1991; Tarrow 1998). The diversity of approaches used to study different forms of collective action also vary widely. Some researchers focus their attention on the media and its impact on social movement actors (McAdam et al. 1996), while others look at the impact of poverty and social class on the rise of social movements (Piven and Cloward 1977; Piven and Cloward 1988). There are yet other scholars who explore identity factors and the emergence of new sets of common interests that unite disparate peoples across great physical distances and from different cultures and political systems (Laclau 1985; Melucci 1996; Slater 1985). As if the breadth of different modes of inquiry into social movements weren't enough, researchers also work on groups of vastly differing sizes. William Gamson conducted a series of controlled laboratory experiments with small groups of individuals in order to study the way that collective action frames are constructed through small group conversations (Gamson 1992). On the other hand, Charles Tilly, Theda Skocpol and Sydney Tarrow have studied social revolutions at the national and cross-national levels. When normal outlets of human expression remain choked, catharsis finds its likely way - either through slogans or rocks or other means of violent expression. There are reasons why despite the establishment of a 'democratic' political order in Jammu \& Kashmir, the anger on its streets remains. The fundamental reason is political. There is a feeling of political and economic disempowerment. Kashmiri youth, faced with a strong state and its security apparatus, also nurse feelings of helplessness and powerlessness. Dissent, peaceful or otherwise, has almost always meant persecution. Some youth also tend to see their religious identity under attack. The cumulative result is accumulated anger.

\section{Theoretical Background:-}

If political values and current political behaviour can be considered necessary indicators of the democracy a given society has gained (Badescu, 2006), it becomes clear that there are still serious problems that need to be addressed. According to Juris Rozenvalds (2007), the challenges are related to gained the political activity of citizens, the democratization of political culture and development of socio-economic pre-conditions for democracy. In fact, many scholars (Howard, 2003 ; Rose \& Shin, 2001, among others) have raised concerns over the political disinterest and the lack of notable developments in political stance among the citizens. Yet, the causes behind this are still not completely understood.

The cultural approach emphasizes the role of combined experiences of a nation, its traditions and history. It reflects on political views and behaviors to be primarily influenced by the political culture in which one has grown up. The beliefs of people and the way they elect to behave are seen largely as a result of early-life socialization. Both individual and collective experiences, such as persistence of a repressive regime, matter. In this sense, the values and habits of individuals can be seen as 'path-dependent' and resistant to change. This approach has been very popular among researchers of post-communist countries. From the point of view of cultural theories the disenchantment of citizens from politics and their civic passivity is a legacy of the communist regime. It is believed to have undermined interpersonal trust, discouraged any out-systemic initiatives and created a very specific type of political culture characterized by political apathy, skepticism and distrust towards authorities (Rose \& Shin, 2001 ; Fields, 2003 ; Putnam, Leonardi, \& Nanetti, 1993 ; Howard, 2003 ; Inglehart, 2006, 1997, 1999 ; Sztompka, 1998 ; _Ijabs, I., 2007).

From the perspective of social capital theories civic ineptitude and passiveness is a result of insufficient transmission of democratic norms, skills and values trough family, school, workplace and voluntary associations (Putnam et al., 1993 ; Almond \& Verba, 1989 ; Pateman, 1975 ; Pietrzyk-Reeves, 2008 ; Brehm \& Rahn, 1997 ; Stolle \& Rochon, 1999 ; Uslaner, 2008). And lack of social confidence is believed to be primarily responsible for the gloomy citizen involvement in political life, and voluntary groups and associations. The social capital theories argue that by interacting with each other, people learn to trust others, reciprocate, acquire self-confidence, belief in the responsiveness of the political system, and all kinds of civic values. These values are then projected onto institutions and result in better informed, more engaged, efficacious, politically active and democratically responsible citizens. This is essentially a bottom up" approach and the role of the public institutions in facilitating social trust and participation are seen as limited.

Even though the cultural approach and the social capital approach are similar, distinguishing between them is very important for policy recommendations, as it shows whether particular political attitudes is something that can be 
influenced relatively easily, or it will take a generation (as suggested by, for example, Eric Uslaner, 2003, Marc Morje Howard, 2003, and Ronald Inglehart, 1999) to achieve a significant change.

From the institutional perspective political attitudes are politically endogenous people build their opinions and expectations on the basis of their prior experiences and their interpretation of these experiences. For example, the lack of confidence in institutions is thought to reflect the dissatisfaction of citizens with the institutional output of political authorities, and their perceived corruption. However, the assumptions of institutional theories stretch farther than confidence in institutions. The perceptions of internal and external efficacy are also believed to be based on individuals previous experience in dealing with institutions (Madsen, 1987 ; Brehm \& Rahn, 1997 ; Stolle, 1998 ; Rothstein \& Stolle, 2003 ; Rothstein, 2004). The institutional approach promotes the 'top-down' development of political attitudes and behaviour, and holds that institutions have a big role in promoting cooperative values and behaviour among the society. The current performance of institutions, i.e., whether they promote growth, avoid corruption, are effective in enforcing laws, as well as whether they prove to be responsive and trustworthy, affects the norms and values that will dominate in the society: the dispositions, expectations and perceptions of people regarding other people, themselves and their role as citizens.

\section{Relevance of the study:-}

The fourth generation of Kashmiris is today doing what the first generation did some 60-70 years ago; they are venting their anger and frustration with the political system through street resistance. Having no platform for expressing their political opinion, they resort to hurling stones.In recent years, stone throwing has strayed out of the confines of downtown Srinagar to spread to other towns of Kashmir. The profile of the stone-thrower has changed too. It's no longer unemployed youth who are fighting this pitched battle. Educated young men are joining in as well. The battleground has expanded from the streets to the internet-Facebook now hosts an application called 'kani jung' where you can throw virtual stones to register your protest.Stone pelters for the last 5-6 years have been defining the contours of Kashmir Politics; challenging the writ of the government in Kashmir. The stone pelting phenomenon and subsequent protests led to the debate of a fresh attitude towards Kashmir and its future. Stone pelters, mostly being the youth, apparent future of Kashmir, it has become important to know who they are, what they think, and mostly what leads them to come on the streets for pelting the stones.

\section{Aims and Objectives:-}

1. To know who are the stone pelters; their age and educational background etc.

2. What prompts them to pelt stones?

\section{Hypothesis:-}

1. The stone pelters are unemployed youth who in absence of a job pelt stones

2. They are paid agents of political parties - Separatists, mainstream parties, businessmen, or others

3. There is a genuine political problem which has created alienation among youth for which they pelt stone to ebb out their anger.

\section{Research Methodology:-}

The purpose of this study was to explore the information, regarding the stone pelters \& reasons that prompt them to pelt stone, researcher used the survey method.The study was done in Srinagar, mainly in Down Town area of the city, the hub of Kani Jang. Here it is more organized with hierarchical Stone-Pelter leadership acting masked, and underneath in perky columns.

\section{Sample:-}

The research was carried out in Srinagar city mainly in the Down Town area. The researcher selected 60 samples (stone pelters) as respondents for the study. Researcher used the snow-ball sampling method and selected 60 respondents with the help of accidental sampling method out of whole population. Every next respondent was selected as identified by the previous respondents. This type of sampling was used, as it is otherwise almost impossible to identify the stone pelters who act unmasked and underneath, not in open.

\section{Methods of data Collection:-}

The researcher used the following methods of data collection.

1. Questionnaire cum interview schedule was prepared by the researcher. The respondents were personally interviewed by the researcher. 
2. Secondary method (Source) - as a secondary method of collecting data was through discussion and observation as well books, journals, internet, magazines, news papers etc.

To have complete view on the existing pattern of stone pelting, who the stone pelters are and why they resort to stone pelting different aspects were studied like age, education, reasons of stone pelting etc.

Age:-

Age is the one of the most important factors of person because age suggests one's thinking and the level of maturity. Researcher wants to know the age of the people involved in stone pelting.

Table No. 1:- Distribution of the Respondent as per Age

\begin{tabular}{|l|l|l|l|}
\hline S. No. & AGE & RESPONDENT & PERCENTAGE \\
\hline 1 & 10 to 18 & 10 & 16.66 \\
\hline 2 & 18 to 25 & 39 & 65 \\
\hline 3 & 25 Plus & 11 & 18.33 \\
\hline & Total & 60 & $100 \%$ \\
\hline
\end{tabular}

The above table shows that out of 60 respondents, 10 to 18 years age Respondents are 16.66 per cent, 18 to 25 years age 65 per cent and 25 plus age 18.33 per cent.

It can be concluded that the majority of stone pelters are youth belonging to 18 to 25 years category.

\section{Educational Qualification of the Respondents:-}

There was this perception that most of the stone pelters are illiterate people who without knowing the outcome of their actions make everything halt. The education level also tells what type of people are involved in stone pelting, and helps to understand the phenomenon better. Table No. 2

\begin{tabular}{|c|c|c|c|}
\hline S. No & $\begin{array}{c}\text { EDUCATIONAL } \\
\text { QUALIFICATION }\end{array}$ & RESPONDENT & PERCENTAGE \\
\hline 1 & ${\text { Up to } 10^{\text {th }}}^{\text {th }}$ & 8 & 13.33 \\
\hline 2 & $10^{\text {th }} 12^{\text {th }}$ & 15 & 25 \\
\hline 3 & Graduation & 17 & 23.33 \\
\hline 4 & Post graduation & 14 & 10 \\
\hline 5 & Illiterate & 6 & $100 \%$ \\
\hline & Total & 60 & \\
\hline
\end{tabular}

The table shows that majority ( 28.33 per cent) of the Respondents are college graduates, 25 per cent have studied up to 12 th class, 23.33 per cent are graduate plus, and 13.33 per cent are below 10th standard. Whereas, only 10 per cent of the respondents are illiterate, making it clear that most of the stone pelters are not illiterate but belong to educated class, who 'know' what they are doing.

\section{Occupation of the Respondents:-}

The authorities had claimed that the stone pelters are unemployed youth who in absence of job resort to this type of action thus terming it a mere employment problem. The researcher looking at the occupation of the respondents wants to know if this claim is right or not. Also, occupation helps to know what type of people are involved in stone pelting.

Table No. 3:-

\begin{tabular}{|c|c|c|c|}
\hline S. No. & OCCUPATION & RESPONDENT & PERCENTAGE \\
\hline 1 & Student & 19 & 31.66 \\
\hline 2 & Privately Employed & 23 & 38.33 \\
\hline 3 & Govt. Employed & 7 & 11.66 \\
\hline 4 & Working for a Political Party & 7 & 11.66 \\
\hline 5 & Staying at home/ Unemployed & 4 & 6.66 \\
\hline & Total & 60 & $100 \%$ \\
\hline
\end{tabular}


The table shows that only 6.66 per cent of the respondents are unemployed, where are the rest are involved in some work. Though there is a large (31.66 per cent) of respondents are students, but being students does not make them unemployed as they are yet to finish their studies and look for job. Thus the claim that the stone pelting is an unemployment problem is not correct, as the data proves.

\section{Working for political party:-}

Table No. 3 shows that 11.66 per cent of people work for political parties, the researcher wants to know that whether they work for mainstream parties or separatists.

Table 4:-

\begin{tabular}{|c|c|c|c|}
\hline S.No. & Working for a political party & Respondent & Percentage \\
\hline 1 & Pro-India/Mainstream & 2 & 28.57 \\
\hline 2 & Pro-Independence/Separatists & 5 & 71.42 \\
\hline & Total & 7 & 100 \\
\hline
\end{tabular}

The table shows majority (71.42 per cent) of the respondents work with separatists where as the rest (28.57 per cent) work with the mainstream parties

Religious Ideology:-

Religion plays an important part in Kashmir politics with everything being seen into religious context. Kashmir being a Muslim majority place with moderate religious perceptions but over the time people have become more conservative in religious nature. The researcher wanted to know how the stone pelters opine on this line, to understand the motivation for their actions.

Table 5:-

\begin{tabular}{|c|c|c|c|}
\hline S.No. & Religious ideology & Respondent & Percentage \\
\hline 1 & Conservative/orthodox & 37 & 61.66 \\
\hline 2 & Moderate/unorthodox & 23 & 38.33 \\
\hline & Total & 60 & 100 \\
\hline
\end{tabular}

The table shows that majority (61.66 per cent) of the respondents are from the conservative/orthodox thought of religion where as the rest (38.33 per cent) favor moderate view of religion. So, religious conservatism also motivates people to pelt stones in Kashmir.

\section{Arrested any time During Stone Pelting:-}

The researcher wanted to know about the 'criminal' background of the stone pelters, if any and what was the reason of crime, if arrested any time.

Table No. 6:-

\begin{tabular}{|c|c|c|c|}
\hline S.No. & No.of times arrested & Respondents & Percentage \\
\hline 1 & Once & 15 & 25 \\
\hline 2 & Twice & 7 & 11.66 \\
\hline 3 & Thrice or more & 5 & 8.33 \\
\hline 4 & Never & 33 & 55 \\
\hline
\end{tabular}

The table shows that only 45 per cent (approx) of the respondents have been arrested during stone pelting. Among them 8.33 percent thrice or more, 11.66 percent twice, and 25 per cent once. This also proves that there are equal chances that people if arrested during stone pelting will come again on the streets and pelt stones when released.

\section{Reason for Pelting Stones:-}

This is one of the main objectives of the research. The researcher wanted to know the reason that makes the youth to come on the streets and pelt stones.

Table 7:-

\begin{tabular}{|c|c|c|c|}
\hline S.no. & Reason for stone pelting & Respondents & Percentage \\
\hline 1 & $\begin{array}{c}\text { Pent-out anger } \\
\text { /frustration }\end{array}$ & 43 & 71.66 \\
\hline 2 & Fun & 10 & 16.66 \\
\hline 3 & Get paid for & 7 & 11.66 \\
\hline
\end{tabular}


The table and diagram shows that 71.66 per cent of the respondents pelt stones to pent-out their anger, and 16.66 per cent do it just for fun. Whereas, only 11.66 per cent get paid for pelting stones; Thus one of the hypothesis that stone pelters are paid agents who get money for it majorly proves wrong, concluding that there are other reasons (as shown in the corresponding tables) for which people risk even their lives.

Table No. 7.1:- (1 in Table No.7) Kind of Anger/ Frustratio.n

\begin{tabular}{|c|c|c|c|}
\hline S.no. & kind of anger/alienation & Respondents & Percentage $(\%)$ \\
\hline 1 & Political & 39 & 90.69 \\
\hline 2 & Non-political & 4 & 9.30 \\
\hline & Total & 43 & 100 \\
\hline
\end{tabular}

This table enhances the Table No. 1 findings showing that the anger is mainly (90.69 per cent) political in nature.

Table No. 7.1(a) What Political means (1 in Table No. 7.1)

\begin{tabular}{|c|c|c|c|}
\hline S.NO & Political means to you & Respondents & Percentage \\
\hline 1 & Separatism/independence demand & 29 & 74.35 \\
\hline 2 & Protest against human rights & 8 & 20.51 \\
\hline 3 & Just to oppose government & 2 & 5.12 \\
\hline & Total & 39 & 100 \\
\hline
\end{tabular}

This table is corresponding the Table No. 7.1 results showing that the political anger means separatism mainly (74.35 per cent), and 20.51 per cent do it as protest mark against the human rights violation. Whereas, 5.12 per cent do it just to oppose the government, not happy with the government.

Table No. 7:- 1(b) what non-political means (2 in Table No. 7.1)

\begin{tabular}{|c|c|c|c|}
\hline S.no & Non-political means & Respondents & Percentage \\
\hline 1 & Problems at home & 1 & 25 \\
\hline 2 & Fed up with system & 3 & 75 \\
& Total & 4 & 100 \\
\hline
\end{tabular}

The table shows the non-political nature of anger or frustration. It shows that among the respondents (2 in Table No. 7.1) 33.33 per cent have problems at home where as 66.66 per cent are fed up with the system, that makes them to come on the streets to pelt stones.

Stone pelting makes you feel:-

The researcher wanted to know about the feelings of stone pelters as they pelt stones.

Table No.8:-

\begin{tabular}{|c|c|c|c|}
\hline S.no & Stone pelting makes you to feel & Respondent & Percentage \\
\hline 1 & Good & 13 & 21.66 \\
\hline 2 & Relieved & 13 & 21.66 \\
\hline 3 & Proud & 27 & 45 \\
\hline 4 & Ashamed & 7 & 11.66 \\
\hline
\end{tabular}

The table shows that only 11.66 per cent of the respondents get compelled to pelt stones, and are not happy with their action but the majority do it for feeling good (21.66 per cent), relieved (21.66 per cent), where as 45 per cent feel proud for their action.

\section{Hypothesis Testing:-}

The stone pelters are unemployed youth who in absence of a job pelt stones.

The data in Table No. 3 shows only 6.66 per cent of the people are unemployed where as the rest are somehow involved in work. Though, a majority (31.66 per cent) of them is students but being students does not make them unemployed. So the hypothesis proves wrong.

Stone pelters are paid agents of political parties - Separatists, mainstream parties, businessmen, or others.

Table No. 7 proves this statement that 'the stone pelters are paid agents' wrong. It shows that only 11.66 per cent of the people get paid where as the rest do it of their own, for the reason as the data proves in other tables. 
There is a genuine political problem which has created alienation among youth for which they pelt stone to ebb out their anger.

Table No 7 clearly shows that there is a deep feeling of anger and frustration (71.66 per cent) which compels and makes up the people for pelting stones to vent it out. And, the anger is more political in nature as the data shows in the sub tables (Table No 7.1 and Table No. 7.2)

\section{Conclusion:-}

As the gun has taken the back seat, slogans, street protests and hurling stones are the order of the day. It is easy to attribute this street resistance to acts of 'miscreants' or 'anti-social elements', but ignoring the underlying factors constitutes a grave folly. It would be wiser to acknowledge that in an environment of political and economic suffocation, this street resistance means psychological catharsis. There is a clear action and reaction pattern involved. Understanding the psychology of those who are detained and tortured is critical. These youngsters engage in means of peaceful resistance - sometimes even stone pelting - because the soldier on the street to them represents a political and military occupation. Undignified treatment to an angry young man during detention hurts his self respect. A slap or a punch on his face creates a deeper disillusionment in his mind. It reinforces his belief that no political system would work for him except the one of Azadi. It even rekindles emotions of revenge. Most importantly, it radicalizes his thoughts and visions of resistance. Suppression often leads to greater disquiet. And then angry young men don't remain averse to violence.

Political, administrative and security measures have failed in Kashmir because the governments in Srinagar and in New Delhi have not yet comprehended the differences between the separatist politics of the older and younger generations. 50\% of Kashmir's youth is under 19 and their stand on Kashmir further hardens when leadership, both in Srinagar and New Delhi, keeps them under constant confusion regarding the status of Kashmir and future options. Kashmiri leadership clearly states that Kashmir is a political dispute. They, however, never declare the minimum they would be prepared to grant. New Delhi does this in a more dangerous way. When 63 years after accession, the Home Minister declares that "Kashmir acceded to India in unique circumstances, it has unique problems and needs unique solutions". Leadership in Delhi has never clearly said what is negotiable and non-negotiable. The third generation in the Valley is completely different from its predecessors. The first generation showed faith in leadership, the second generation was in search of new leaders and the third generation doesn't want any leaders. It is time for India to be frank and express to these angry youths, the maximum they should expect. If they agree, well and good if they don't, at least the country and the Kashmiri youths will be in better know of their future course of action.

They are being called the children of conflict, but the stone throwers in Kashmir today represent a connection with their political history free of the distorting prisms that for long have twisted the local worldview and their aspiration of a future outside the Indian union. The identity of a stone-pelter became something that an average Kashmiri began to feel proud of, the frontline of the articulation of a political demand. For, he is young, educated, angry, brutalized and politically aware. He demands to be heard, to express what he wants, thinks and feels. He supports what his earlier avatar, the armed militant, stood for.Kashmir has witnessed generations of its youth, espousing secular nationalist ideals for achieving Kashmir's political goals, eventually embracing a radical religious worldview. Failure of secular, peaceful and democratic means in achieving political goals often leads to an embrace of a religious political ideology. And then the consequences prove disastrous. It is time to break away from the lawand-order approach in dealing with the Kashmiri youth anger. The new approach has to be political, and humane.

\section{References:-}

1. Almond, G., \& Verba, S. (1989). The civic culture revisited: An analytical study. Thousand Oaks, CA: Sage Publications.

2. Badescu, G. (2006). Historical and cultural borderlines in eastern Europe. In H. Klingemann, D. Fuchs, \& J. Zielonka (Eds.), Democracy and Political Culture in Eastern Europe , 85-97.

3. Brehm, J., \& Rahn, W. (1997). Individual - level evidence for the causes and consequences of social capital. American Journal of Political Science, 41 (3), 999-1023.

4. Fields, J. (2003). Social capital (Key ideas). New York, NY: Rutledge

5. Gamson, W. A. (1992). Talking politics. Cambridge university press.

6. Goldstone, J. A. (1991). Revolution and rebellion in the early modern world. Univ of California Press. 
7. Howard, M. (2003). The weakness of civil society in post-communist Europe. Cambridge: Cambridge University Press.

8. Inglehart, R. (1997). Modernization and postmodernization: Cultural, economic, and political change in 43 societies. Princeton, NJ: Princeton University Press.

9. Inglehart, R. (1999). Postmodernization erodes respect for authority, but increases support for democracy. In P. Norris (Ed.), Critical Citizens: Global Support for Democratic Government (p. 236-56). New York, NY: Oxford University Press.

10. Inglehart, R. (2006). East European value systems in global perspective. In H. Klingemann, D. Fuchs, \& J. Zielonka (Eds.), Democracy and Political Culture in Eastern Europe (pp. 67 $\{84)$. New York, NY: Routledge

11. McAdam, D. (1996). Conceptual origins, current problems, future directions. Comparative perspectives on social movements: Political opportunities, mobilizing structures, and cultural framings, 23-40.

12. Melucci, A. (1996). Challenging codes: Collective action in the information age. Cambridge University Press.

13. Pateman, C. (1975). Participation and democratic theory (structural analysis in the socialsciences). Cambridge: Cambridge University Press.

14. Pietrzyk-Reeves, D. (2008). Weak civic engagement? post-communist participation and democratic consolidation. Polish Sociological Review, 161 (1), $73\{87$.

15. Piven, F. F. and Richard A. Cloward 1977 Poor People's Movements: Why They Succeed, How They Fail. New York: Pantheon.

16. Putnam, R., Leonardi, R., \& Nanetti, R. (1993). Making democracy work: Civic traditions in modern Italy. Princeton NJ: Princeton University Press.

17. Rose, R., \& Shin, D. (2001). Democratization backwards: The problem of third-wave democracies. British Journal of Political Science, 31 (2), $331\{54$.

18. Stolle, D., \& Rochon, T. (1999). The myth of American exceptionalism. In J. Van Deth (Ed.), Social Capital and European democracy (pp. 192-209). London: Routledge.

19. Sztompka, P. (1998). Introduction. The lessons of 1989 for sociological theory. In P. Sztompka (Ed.), Building Open Society and Perspectives of Sociology in East-central Europe). Montreal: University of Quebec Press. pp. 9-24

20. Tarrow, S. (1998). Fishnets, internets, and catnets: Globalization and transnational collective action. Challenging authority: The historical study of contentious politics, 228-244.

21. Uslaner, E. (2008). Trust as a moral value. In D. Castiglione, J. van Deth, \& Wolleb.G. (Eds.), The handbook of social capital New York, NY: Routledge. 101-21.

\section{Newspapers:-}

1. Daily Greater Kashmir, Srinagar Kashmir

2. Daily Kashmir Times, Srinagar Kashmir

3. The Indian Express, Delhi - Jammu Edition

4. Hindustan Times, New Delhi

5. Economic Times, New Delhi

Magazines and Journals:

Outlook, New Dlehi

Frontline, New Delhi

Economic \& Political Weekly, Mumbai 